\title{
Thyroid storm due to head injury
}

\author{
Gülşah Yılmaz Karaören, M.D., ${ }^{1}$ Omer Torun Sahin, M.D., ${ }^{1}$ \\ Zeynel Abidin Erbesler, M.D., ${ }^{2}$ Nurten Bakan, M.D. ${ }^{1}$
}

${ }_{1}^{1}$ Department of Anaesthesiology and Reanimation, Istanbul Umraniye Training and Research Hospital, Istanbul;

${ }^{2}$ Department of Anaesthesiology and Reanimation Van Ercis State Hospital, Van

\begin{abstract}
In this case report, we would like to present a 36-year-old male patient injured in a street fight without any disease previously known, who was accepted to our intensive care unit with the preliminary diagnoses of minimal cerebral contusion and aspiration pneumonia however by the physical examination, clinical and laboratory findings, was diagnosed as thyroid storm due to trauma. In the current literature, only a few cases reported showing thyroid storm-induced by trauma, and we would like to present the clinical features and management of this life-threatening endocrinological emergency.
\end{abstract}

Key words: Aspiration; brain contusion; complications-trauma; hyperthyroidism; pneumonia; thyrotoxic storm.

\section{INTRODUCTION}

Thyroid storm is a rare, but life-threatening endocrinological emergency characterized by severe clinical manifestations of thyrotoxicosis. Incidence of this hyperthyroidism state is about $1-2 \%^{[1]}$ with high mortality rates, of $20-30 \% .{ }^{[2]}$ There is consensus among authors that the conversion from thyrotoxicosis to thyroid storm is caused by a precipitating event. Although rare, trauma is one such trigger. ${ }^{[2]}$

Thyroid storm symptoms and signs may vary and are mainly non-specific due to the widespread effects of thyroid hormones. ${ }^{[3]}$ For the limitation of mortality and morbidity, early diagnosis and treatment are essential.

In this report, we describe the importance of neck examination with palpation of the thyroid gland in a 36-year-old trauma patient.

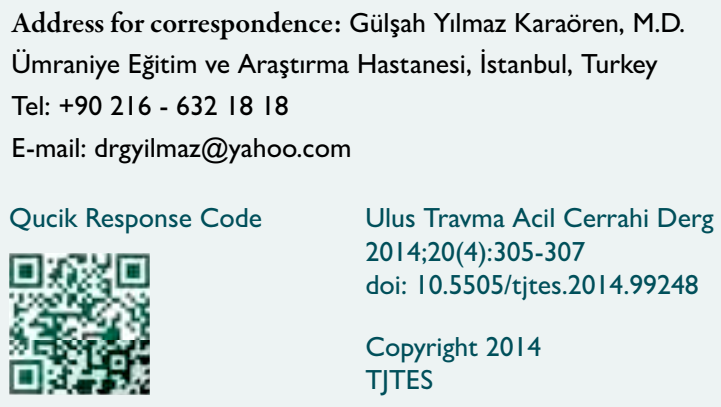

\section{CASE REPORT}

A 36-year-old male injured in a street fight presented at the emergency department. His relatives said that he was healthy before his admission. He was not taking any medication, had no known allergy, no family history of inherited disease, and no alcohol or recreational drug use.

His Glasgow coma score (GCS) remained at 13 in the resuscitation room, and he was irritable. On a primary survey, he was tachypneic (40/min) tachycardic (120 bpm), and his blood pressure (BP) was $160 / 90 \mathrm{mmHg}$. His pupils were isochoric and reactive to light. As the GCS decreased from I3 to II, a head injury was suspected. Tomographic scanning of the thorax, head, and cervical spine was performed, and a minor left temporal contusion was determined. The patient was admitted to the neurosurgery department for further follow-up.After 10 hours, the patient became unresponsive to verbal and tactile stimuli, and GCS decreased to 5. The pupils were normal and reactive, and he had no lateralization signs. Heart rate (HR) was I $30 \mathrm{bpm}, \mathrm{BP}$ was $170 / 90 \mathrm{mmHg}$, and core temperature (CT) was $38.7^{\circ} \mathrm{C}$. Respiratory rate was $40 / \mathrm{min}$ and breath sounds were noisy with inspiratory rales. Blood-gases showed $\mathrm{pH} 7.3$ $\mathrm{mmHg}, \mathrm{pO}_{2} 77 \mathrm{mmHg}$, and $\mathrm{pCO}_{2} 31 \mathrm{mmHg}$. The patient was intubated and taken to the radiology department again to see if there had been a recently developed hemorrhage or shift.

No difference was observed between the first and the control cranial tomography scans. The neurosurgery team was of the opinion that the small contusion was not sufficient to explain the low GCS level. 
Finally, he was transported to the intensive care unit (ICU) with a diagnosis of minimal cerebral contusion and pneumonia due to gastric content aspiration.

In the ICU, oxygen saturation was $90 \%$ during mechanical ventilation (continuous positive airway pressure [CPAP]/ pressure support ventilation [PSV], positive end expiratory pressure [PEEP] $8 \mathrm{mmHg}$ pressure support [PS] $15 \mathrm{mmHg}$ ) with the fraction of inspired oxygen of 0.5 . He was sedated with midazolam $5 \mathrm{mg} / \mathrm{kg}$ and remifentanil $0.25 \mu \mathrm{g} / \mathrm{kg}$ infusions.

The pupils were observed to be round and reactive, and the neck was supple. He had a minimally enlarged thyroid gland with no bruit or evident nodule. The trachea was in the midline and auscultation of the chest demonstrated crackles. Cardiac examination revealed tachycardia (I40 bpm) and BP

Table I. Scoring system to diagnose thyroid storm*

\begin{tabular}{|c|c|}
\hline Diagnostic parameters & Point \\
\hline \multicolumn{2}{|l|}{ Thermoregulatory dysfunction, ${ }^{\circ} \mathrm{F}$} \\
\hline $99.0-99.9$ & 5 \\
\hline $100.0-100.9$ & 10 \\
\hline $101.0-101.9$ & 15 \\
\hline $102.0-102.9$ & 20 \\
\hline $103.0-103.9$ & 25 \\
\hline$\geq 104.0$ & 30 \\
\hline \multicolumn{2}{|l|}{ Central nervous system dysfunction } \\
\hline Mild (agitation) & 10 \\
\hline Moderate (delirium, psychosis, extreme lethargy) & 20 \\
\hline Severe (seizures, coma) & 30 \\
\hline \multicolumn{2}{|l|}{ Gastrointestinal dysfunction } \\
\hline Moderate (diarrhea, nausea/vomiting, abdominal pain) & 10 \\
\hline Severe (unexplained jaundice) & 20 \\
\hline \multicolumn{2}{|l|}{ Cardiovascular dysfunction: tachycardia, beats/min } \\
\hline $90-109$ & 5 \\
\hline $110-119$ & 10 \\
\hline $120-139$ & 15 \\
\hline$\geq 140$ & 25 \\
\hline \multicolumn{2}{|l|}{ Cardiovascular dysfunction: congestive heart failure } \\
\hline Mild (pedal edema) & 5 \\
\hline Moderate (bibasilar rales) & 10 \\
\hline Severe (pulmonary edema) & 15 \\
\hline \multicolumn{2}{|l|}{ Cardiovascular dysfunction: atrial fibrillation } \\
\hline Present & 10 \\
\hline \multicolumn{2}{|l|}{ Precipitating event } \\
\hline Present & 10 \\
\hline
\end{tabular}

A score $\geq 45$ is highly suggestive of thyroid storm. A score of 25 to 44 supports the diagnosis of thyroid storm. A score $<25$ is unlikely to be thyroid storm. Adapted from Burch and Wartofsky. ${ }^{[4]}$ was 170/74 $\mathrm{mmHg}$. Diffuse erythema on the face and chest was seen on skin examination. His CT was $39^{\circ} \mathrm{C}$.

Ceftriaxone was administered after blood and tracheal aspiration cultures were obtained.

Laboratory evaluation determined normal electrolyte, hepatic, and renal panels. White blood cell was 7500 cells $/ \mathrm{mL}$, hemoglobin, I I.4 g/dL, and platelet, 140,000 cells $/ \mathrm{mL}$. The arterial lactate level was $10 \mathrm{mg} / \mathrm{dL}$ (normal, $5-14 \mathrm{mg} / \mathrm{dL}$ ). Urine analysis showed no abnormality.

While the thyroid panel is not routinely evaluated in our ICU, we decided to obtain one because of the enlarged thyroid gland. After 12 hours in the ICU, the patient remained critically ill with CT of $40^{\circ} \mathrm{C}$ despite IV paracetamol. HR was 140 bpm and BP was $180 / 90 \mathrm{mmHg}$. After 24 hours, the thyroid function tests were reported. The thyroid-stimulating hormone (TSH) was $0.000 \mathrm{I} \mathrm{ulU/mL,} \mathrm{FT3,} \mathrm{II.29} \mathrm{(nor-}$ mal, I.7I-3.7I) pg/mL, and FT4, 3.3 (normal, 0.7-I.49) $\mathrm{pg} / \mathrm{mL} \cdot{ }^{[1]}$

A diagnosis of thyroid storm due to head injury was considered. According to the Burch and Wartofsky scoring system, a score of 45 or more is highly suggestive of thyroid storm; thus, the patient met the criteria with a score of 70 (Table I). ${ }^{[4]}$

Therapy was started of propylthiouracil (PTU) $100 \mathrm{mg} / 4$ hour, propranolol $40 \mathrm{mg} / 8$ hour, and methylprednisolone $1 \mathrm{mg} / \mathrm{kg}$ and esmolol $50-100 \mu \mathrm{g} / \mathrm{kg} / \mathrm{min}$ infusion. No iodine or hydrocortisone preparation was available. There was a significant improvement in his hemodynamics after the 24th hour of medication. Large boluses of fluid were administered due to fever and sweating. CVP was $8-10 \mathrm{mmHg}$. On the 3rd day of ICU admission, FT3 level gradually decreased to $7.2 \mathrm{pg} / \mathrm{mL}$ and FT4 level was $2.2 \mathrm{pg} / \mathrm{mL}$; on the 9th day, FT3 was $3.4 \mathrm{pg} / \mathrm{mL}$, FT4 was $1.85 \mathrm{pg} / \mathrm{mL}$, and TSH was $0.0004 \mathrm{ulU} / \mathrm{mL}$.

The patient was extubated on the 4th day. There was a gradual improvement in mental status from the minor contusion. He was advised to follow routine endocrinology controls and was discharged to the neurosurgery department on the 9th day of ICU admission.

\section{DISCUSSION}

Thyroid storm is the most serious complication of hyperthyroid state and even with treatment, has a high risk of mortality. ${ }^{[3]}$ There are few case reports in literature, which mention trauma as a precipitating event of thyroid storm. ${ }^{[5]}$

The incidence is $<10 \%$ of the patients interned to hospital for thyrotoxicosis, and it is generally related to a precipitating event, such as comorbid conditions, infec- 
tion, thyroid or non-thyroidal surgery, pulmonary embolism, pre-eclampsia, emotional stress, or withdrawal of anti-thyroid medications. ${ }^{[6]}$ The progression of thyrotoxicosis to thyroid storm is difficult to predict.

There is no pathognomonic constellation of signs and symptoms as thyroid storm is so variable in terms of presentation. In some cases, hyperglycemia, leukocytosis, elevated plasma calcium levels and abnormal liver function tests may be seen. [5] The diagnosis of a thyroid storm is based upon clinical findings. ${ }^{[1]}$ Patients with thyroid storm can manifest fever, nausea, vomiting, diarrhea, and jaundice (gastrointestinal or hepatic dysfunction), nervous system disorders, arrhythmia, and other cardiovascular abnormalities. ${ }^{[2]}$ The patient history and physical examination assist in the differential diagnosis. The physical findings of an enlarged thyroid gland, tachycardia, a widened pulse pressure, fever, tachypnea, lid lag, hand tremor, warm and moist skin, depressed mental status and ophthalmopathy (in the presence of Graves' disease) are all consistent with thyroid storm. Although TSH is generally undetectable, a low thyrotropin (TSH) level also supports the diagnosis. ${ }^{\left[{ }^{[3]}\right.}$

In the case presented here, it seems that a pre-existing and untreated abnormality of the thyroid gland was responsible for the clinical picture. On the basis of this constellation of findings, the most likely diagnosis was thyroid storm, precipitated by trauma, in a patient with pre-existing hyperthyroidism.

Treatment includes regulation of the hyperthyroid state with anti-thyroid medications. In addition to thioamides, iodine may be administered to decrease thyroid hormone synthesis. It is essential to restore homoeostasis with IV hydration, and betaadrenergic blockers may be required to control cardiovascular manifestations. Glucocorticoids can be used to inhibit the conversion of thyroxine (T4) to triiodothyronine (T3) ${ }^{[7]}$ PTU decreases new hormone production and peripheral de-iodination of T4 to T3. It should be noted that PTU is no longer recommended as a first-line agent in the management of Graves' disease, due to safety concerns related to liver failure. ${ }^{[8]}$

In the current case, the absence of a suitable iodine preparation forced us to use PTU instead, and we followed the hepatic panel carefully.
Vasomotor abnormalities can be aggravated by fever and should be treated with antipyretics. However, aspirin should be avoided as it induces decreased binding of T3 and T4 to thyroxine-binding globulin. ${ }^{[3]}$ Treatment with paracetamol, as an alternative drug, can be useful without side-effects.

When clinical deterioration occurs despite aggressive medical therapy, thyroid hormone can be removed directly by plasmapheresis, charcoal, resin hemoperfusion, or plasma exchange. ${ }^{[9]}$ In the current case, these aggressive treatment methods were not required.

This case demonstrated the importance of a neck examination with palpation of the thyroid gland. Early recognition with a full clinical history and physical examination and aggressive treatment are fundamental in limiting the morbidity and mortality associated with this endocrine emergency.

Written informed consent was obtained from a family member of the patient.

\section{Conflict of interest: None declared.}

\section{REFERENCES}

1. Karger S, Führer D. Thyroid storm--thyrotoxic crisis: an update. [Article in German] Dtsch Med Wochenschr 2008;133:479-84. [Abstract] CrossRef

2. Vora NM, Fedok F, Stack BC Jr. Report of a rare case of trauma-induced thyroid storm. Ear Nose Throat J 2002;81:570-4.

3. Graham BB, Burnham EL, Janssen JS, Janssen WJ. Dyspnea, chest pain, and altered mental status in a 33-year-old carpenter. Chest 2008;134:1074-9. CrossRef

4. Burch HB, Wartofsky L. Life-threatening thyrotoxicosis. Thyroid storm. Endocrinol Metab Clin North Am 1993;22:263-77.

5. Wilkinson JN. Thyroid storm in a polytrauma patient. Anaesthesia 2008;63:1001-5. CrossRef

6. Malchiodi L. Thyroid storm: recognizing the signs and symptoms of this life-threatening complication. American Journal of Nursing 2002;102:33-5. CrossRef

7. Birrell G, Cheetham T. Juvenile thyrotoxicosis; can we do better? Arch Dis Child 2004;89:745-50. CrossRef

8. Rivkees SA, Mattison DR. Ending propylthiouracil-induced liver failure in children. N Engl J Med 2009;360:1574-5. CrossRef

9. Ashkar FS, Katims RB, Smoak WM 3rd, Gilson AJ. Thyroid storm treatment with blood exchange and plasmapheresis. JAMA 1970;214:1275-9.

\title{
OLGU SUNUMU - ÖZET
}

\section{Kafa travmasına bağlı tiroit firtınası \\ Dr. Gülşah Yılmaz Karaören, ${ }^{1}$ Dr. Omer Torun Sahin, ${ }^{1}$ Dr. Zeynel Abidin Erbesler, ${ }^{2}$ Dr. Nurten Bakan ${ }^{1}$}

\author{
1'istanbul Ümraniye Eğitim ve Araştırma Hastanesi, Anesteziyoloji ve Reanimasyon Kliniği, İstanbul; \\ ${ }^{2}$ Van Ercis Devlet Hastanesi, Anesteziyoloji ve Reanimasyon Kliniği, Van \\ Bu yazıda, önceden bilinen bir hastalığı olmayan, sokak kavgasında yaralanma sonrasında yoğun bakıma minimal serebral kontüzyon ve aspirasyon \\ pnömonisi ön tanıları ile alınan, ancak fiziksel inceleme ve labaratuvar bulguları sonucunda travmaya bağlı gelişen tiroit fırtınası tanısı konulan 36 \\ yaşındaki erkek hasta sunuldu. Mevcut literatürde travmanın indüklediği tiroit fırtınası sadece birkaç olguda bildirilmiştir. Biz de, bu hayatı tehdit eden \\ endokrinolojik acilin özelliklerini ve anestezik yönetimini sunmayı amaçladık. \\ Anahtar sözcükler: Aspirasyon; beyin kontüzyon; komplikasyonlar-travma; hipertiroidizm; pnömoni; tirotoksik firtına.
}

Ulus Travma Acil Cerrahi Derg 20 14:20(4):305-307 doi: 10.5505/tjtes.2014.99248 